\title{
Analisis Hukum Maladministrasi Pembentukan Desa Definitif pada Pemerintahan Kabupaten Konawe
}

\author{
Analysis of Maladministration Law Definitive Village Establishment Konawe \\ District Government
}

\author{
Irwan Masrun \\ Fakultas Hukum Universitas Halu Oleo \\ E-mail: irwan.masrun86@gmail.com \\ Muh. Jufri Dewa \\ Pascasarjana Universitas Halu Oleo \\ E-mail:muh.jufridewa@yahoo.com \\ Guasman Tatawu \\ Pascasarjana Universitas Halu Oleo \\ E-mail: gtatawu@gmail.com
}

\begin{abstract}
This study aims to analyze the development regime of village formation before and after the enactment of Law No. 6 of 2014 and to analyze the implications of norms for the formation of maladministration villages. This study uses normative law research type (legal research) with research shorts that include statute approach, case approach and conceptual approach with primary and secondary legal materials with prescriptive analysis techniques. The development regime of village formation before and after the enactment of Law No. 6 of 2014 undergoes several changes related to the legal policy of village formation before the enactment of the law on village formation into the authority of the Level II Government which then the authority of village formation must be through the decision of the Minister of Home Affairs which subsequently the formation of the village is reorganized and the authority of village formation is returned to the Local Government but has not set about the terms of the number of residents and the number of family heads as a condition of formation. After the enactment of the Village Law village formation has been regulated at the level of legislation where the terms and conditions of village formation are contained in article 8 paragraph 3 letter b to 6. Village Law No. 6 of 2014 on Villages. In terms of implications for the norm of the formation of maladministration village, the establishment of the village as the norm of the order is a right that the local government can form a village that must be preceded by village preparation for 5 years with terms and conditions and its establishment refers to article 8 paragraph 3 letter $b$ to 6 of village law No. 6 of 2014 on Villages. Against the norm of prohibition on the formation
\end{abstract}


of villages in Konawe Regency from the results of the study found that the formation of villages has violated the norms of prohibition because it does not meet the requirements of village formation as referred to in Village Law No. 6 of 2014.

Keyword: Maladministration; Formation; Village

\begin{abstract}
Abstrak: Penelitian ini bertujuan untuk menganalisis rezim perkembangan pembentukan desa sebelum dan sesudah berlakunya Undang-Undang Nomor 6 Tahun 2014 serta untuk menganalisis implikasi norma atas pembentukan desa yang maladministrasi. Penelitian ini menggunakan tipe penelitian hukum normatif (legal research) dengan pendekatan penelitian yang meliputi pendekatan undang-undang (statute approach), pendekatan kasus (case approach) dan pendekatan konseptual (conseptual approach) dengan bahan hukum primer dan sekunder dengan teknik analisis yang bersifat preskriptif. Rezim perkembangan pembentukan desa sebelum dan sesudah berlakunya Undang-Undang Nomor 6 Tahun 2014 mengalami beberapa perubahan terkait kebijakan hukum pembentukan desa sebelum berlakunya undang-undang tentang desa pembentukan desa menjadi kewenangan Pemerintah Tingkat II yang kemudian kewenangan pembentukan Desa harus melalui keputusan Menteri Dalam Negeri yang selanjutnya pembentukan Desa diatur kembali dan kewenangan pembentukan desa dikembalikan kepada Pemerintah Daerah namun belum mengatur tentang syarat jumlah penduduk dan jumlah kepala keluarga sebagai syarat pembentukan. Setelah berlakunya Undang-Undang Desa pembentukan Desa telah diatur pada level peraturan undang-undang dimana syarat dan ketentuan pembentukan desa tertuang di dalam pasal 8 ayat 3 huruf b ke 6. UndangUndang Desa Nomor 6 Tahun 2014 tentang Desa. Dalam hal implikasi atas norma pembentukan desa yang maladministrasi maka pembentukan desa sebagai norma perintah merupakan suatu hak dimana pemerintah daerah dapat membentuk desa yang harus didahului desa persiapan selama 5 tahun dengan syarat dan ketentuan dan pembentukannya mengacu pada Pasal 8 ayat (3) huruf b angka 6 Undang-Undang Desa Nomor 6 Tahun 2014 tentang Desa. Terhadap norma larangan atas pembentukan desa di Kabupaten Konawe dari hasil penelitian ditemukan bahwa pembentukan desa telah melanggar norma larangan karena tidak memenuhi syarat pembentukan desa sebagaimana yang dimaksud dalam Undang-Undang Desa Nomor 6 Tahun 2014.
\end{abstract}

Kata kunci: Maladministrasi; Pembentukan; Desa

\title{
PENDAHULUAN
}

Pembentukan desa di Indonesia sering kali mengalami perubahan pengaturan hukum yang telah terjadi di beberapa rezim pemerintahan baik di zaman orde lama, orde baru maupun orde reformasi. Siklus kewenangan pembentukan desa merupakan domain dari Pemerintah Daerah yang kemudian dikembalikan oleh Pemerintah Pusat dan kemudian dikembalikan kembali kepada Pemerintah Daerah seiring dengan pelaksanaan sistem desentralisasi.

Desa merupakan kesatuan masyarakat hukum yang memiliki batas wilayah yang berwenang untuk mengatur dan mengurus urusan pemerintahan, kepentingan masyarakat setempat berdasarkan prakarsa masyarakat, hak asal usul, dan/atau hak tradisional yang diakui 
dan dihormati dalam sistem Pemerintahan Negara Kesatuan Republik Indonesia1. Konsepsi tersebut tertuang di dalam ketentuan Pasal 1 ayat (43) Undang-Undang Nomor 23 Tahun 2014 tentang Pemerintahan Daerah. Penduduk desa pada umumnya saling mengenal, hidup bergotong-royong, memiliki adat istiadat yang sama, dan mempunyai tata cara sendiri dalam mengatur kehidupan kemasyarakatannya.

Melalui Undang-Undang Nomor 23 Tahun 2014 tentang Pemerintahan Daerah, sistem Pemerintahan Indonesia tidak lagi sentralistis, namun telah memberikan peran lebih kepada Pemerintah Daerah untuk melakukan penataan Daerah Otonom Baru. Isu Daerah Otonom Baru menjadi penting saat ini dan bahkan menjadi fokus pemerintah dalam menata percepatan pembangunan di berbagai sektor khususnya terkait dengan pemekaran wilayah.

Kebijakan Otonomi Daerah memunculkan kebijakan desentralisasi. Dimana desentralisasi pada dasarnya membawa konsekuensi pada pembentukan daerah otonom dan penyerahan kuasa ke daerah otonom. Melalui pemekaran daerah atau wilayah. Pada pembentukan daerah, secara mendasar dimaksudkan untuk meningkatkan pelayanan publik guna mempercepat kesejahteraan masyarakat. Untuk itu maka pembentukan daerah harus mempertimbangkan berbagai persyaratan dan kriteria pembentukan maupun pemekaran sebuah daerah atau desa ${ }^{2}$.

Pemekaran wilayah merupakan proses pembagian atau pemecahan satu wilayah otonom yang baru demi tercapainya tujuan pembangunan. ${ }^{3}$ Pembangunan pun seharusnya didasarkan pada kebutuhan dasar dari masyarakat itu sendiri sehingga efektivitas dan efisiensi kinerja pemerintah dapat tercapai, dengan demikian kesejahteraan masyarakat bukan sekedar wacana melainkan sesuatu yang konkret yang dapat dinikmati oleh seluruh lapisan masyarakat ${ }^{4}$ sebagaimana tujuan konstitusional bangsa Indonesia yang tertuang di dalam Undang-Undang Dasar Negara Republik Indonesia Tahun 1945.

1 Penjelasan UU No. 6 Tahun 2014 Tentang Desa. Lihat juga dalam Fatkhul Muin dan Rully Syahrul Mucharom, "Desa dan Hukum Adat: Perspektif Normativitas dan Sosiologis Keindonesiaan", Prosiding Seminar Nasional Multi Disiplin Ilmu \& Call For Papers Unisbank (SENDI_U) Ke-2 Kajian Multi Disiplin Ilmu dalam Pengembangan IPTEKS untuk Mewujudkan Pembangunan Nasional Semesta Berencan (PNSB) sebagai Upaya Meningkatkan Daya Saing Global, Semarang: Universitas Stikubank, 2016, hlm. 461.

2 Hanna Eka Puspitasari dan Andy Fefta Wijaya,Sukanto, "Pemekaran Desa dalam Rangka Peningkatan Pelayanan Publik di Bidang Kesehatan Berkebutuhan Khusus (Studi Pada Desa Sidoharjo, Kec. Sukorejo, Kab. Ponorogo, Jawa Timur)" Jurnal Administrasi Publik (JAP), Vol. 1, No. 2, 2020, hlm. 325

3 Sumarlis, "Kajian Tujuan Pemekaran Desa Menurut Peraturan Pemerintah Nomor 129 Tahun 2000 (Studi Kasus: Desa Kampung Baru Koto Kecamatan Inuman)", Jurnal Perencanaan, Sains, Teknologi, dan Komputer, Vol. 1, No. 1, 2018, hlm. 120.

4 Ibid. 
Pergeseran isu pemekaran daerah tidak lagi pada isu pemekaran Provinsi maupun Kabupaten/Kota, tetapi isu pemekaran semakin banyak pada level pemerintahan desa seiring dengan di berlakukannya Undang-Undang Nomor 6 Tahun 2014 tentang Desa yang ditunjang dengan sistem penganggaran di tingkat desa yang semakin baik karena konsentrasi pemerintah pusat dalam menjamin terlaksananya tujuan bernegara yakni mewujudkan keadilan sosial bagi seluruh rakyat Indonesia dimulai dari desa (button up).

Besarnya alokasi anggaran terhadap desa melalui Anggaran Pendapatan Belanja Negara mendorong berbagai pihak untuk melakukan berbagai bentuk pemekaran dengan tujuan untuk mendapatkan alokasi dana desa sebesar Rp. 1.000.000.000,- (Satu Milyar Rupiah) dengan berbagai cara, dengan pertimbangan makin banyak desa yang terbentuk maka makin besar pula anggaran dana desa yang diperoleh sehingga daya serap Anggaran Pendapatan Belanja Daerah (selanjutnya disebut APBD) tidak perlu terkonsentrasi pada pembangunan desa karena desa sudah dapat mandiri melalui dana desa yang dialokasikan oleh pemerintah pusat.

Salah satu tujuan penting dilakukan pemekaran desa agar pemerintah daerah dapat melakukan percepatan pembangunan ditingkat desa yang secara langsung akan memberikan dampak positif oleh pemerintah daerah dalam pemerataan pembangunan. Alokasi dana desa tersebut meliputi berbagai sektor khususnya pada sektor fisik pembangunan desa yang didasarkan pada kebutuhan dan karakteristik wilayah desa.

Pemekaran desa yang dilakukan oleh pemerintah daerah ternyata menyisakan banyak problem dimana desa-desa yang dibentuk tidak sesuai dengan ketentuan Undang-Undang Desa Nomor 6 Tahun 2014. Pembentukan desa tersebut memiliki problem pada tingkatan prosedural sebagai syarat pembentukan desa. Jika merujuk kepada Undang-Undang Desa syarat-syarat pembentukan desa di setiap daerah provinsi berbeda antara satu dengan yang lain. Ketentuan syarat pembentukan desa di wilayah Provinsi Sulawesi Tenggara dapat dilihat di dalam ketentuan pasal 8 ayat (3) huruf b ke 6 berbunyi: Wilayah Sulawesi Tengah, Sulawesi Barat, Sulawesi Tenggara, Gorontalo, dan Kalimantan Selatan paling sedikit 2.000 jiwa atau 400 kepala keluarga. ${ }^{5}$ Rasio legis dari ketentuan Pasal 8 ayat (3) huruf b di dalam Undang-Undang Desa adalah jika jumlah penduduk dengan tingkat kepadatan yang banyak maka prasyarat jumlah penduduk dalam pembentukan desa akan semakin besar begitu pula sebaliknya daerah yang memiliki jumlah penduduk yang lebih rendah maka prasyarat jumlah penduduk dalam

5 Mimi Kartika, Friska Yolanda, "Kemendagri Usul Pemda Lakukan Evaluasi Desa", Republika, https://republika.co.id/berita/q15xjj370/kemendagri-usul-pemda-lakukan-evaluasi-desa, diakses pada tanggal 14 Juni 2021. 
pembentukan desa juga akan semakin sedikit atau dengan kata lain pembentukan desa didasarkan pada klaster jumlah kepadatan penduduk suatu daerah. Perbedaan syarat pembentukan desa dalam ketentuan Pasal 8 ayat (3) huruf b di dalam Undang-Undang Desa menunjukkan bahwa proses persebaran penduduk dan pembangunan di Indonesia tidak mereta hal ini sebagai konsekuensi logis dari sistem sentralistis yang terjadi sebelum era reformasi.

Kebijakan hukum pembentukan desa yang diamanatkan Undang-Undang Desa ternyata melahirkan permasalahan hukum dalam pembentukan dan pemekarannya. Provinsi Sulawesi Tenggara khususnya Kabupaten Konawe sebagai contoh yang mendapatkan sorotan media nasional bahwa terdapat 56 desa yang tersebar di beberapa kecamatan di Kabupaten Konawe yang terindikasi maladministrasi dalam pembentukannya. Norma pembentukan desa di Kabupaten Konawe meliputi 2 prinsip norma yakni norma perintah dan norma larangan. Dalam penelitian ini akan dielaborasi prinsip tersebut dalam pembentukan desa yang berimplikasi maladministrasi.

\section{METODE PENELITIAN}

Penelitian ini menggunakan tipe penelitian hukum normatif (legal research) dengan pendekatan penelitian yang meliputi pendekatan undang-undang (statute approach), pendekatan kasus (case approach) dan pendekatan konseptual (conseptual approach) dengan bahan hukum primer dan sekunder dengan teknik analisis yang bersifat preskriptif.

\section{ANALISIS DAN PEMBAHASAN}

\section{Rezim Pengaturan Hukum Perkembangan Pembentukan Desa Sebelum dan Sesudah Berlakunya Undang-Undang Desa Nomor 6 Tahun 2014}

Pemerintahan desa adalah bentuk administrasi pemerintahan yang berada pada tingkat paling bawah dalam struktur Pemerintahan Negara Indonesia. Dalam perkembangannya, sistem dan bentuk pemerintah desa mengalami beberapa perubahan sejak Indonesia merdeka sampai dengan masa reformasi. Sejarah pemerintahan desa setelah kemerdekaan dapat dilihat dari aturan-aturan yang muncul mengenai desa dari masa ke masa. Berikut ini penulis akan menguraikan rezim pembentukan desa dalam pendekatan perundang-undangan sebagai berikut. 6

6 Vincentius Gitiyarko, "Sejarah Pemerintah Desa Setelah Kemerdekaan", Kompaspedia, https://kompaspedia.kompas.id/baca/paparan-topik/sejarah-pemerintahan-desa-setelah- 


\section{Setelah kemerdekaan}

Pada masa ini cikal bakal aturan terkait dengan desa beserta sistem administrasinya diatur dalam UUD 1945, Pasal 18. Bunyi pasal ini adalah:

"Pembagian daerah Indonesia atas daerah besar dan kecil, dengan bentuk susunan pemerintahannya ditetapkan dengan undang-undang, dengan memandang dan mengingati dasar permusyawaratan dalam sistem pemerintahan negara, dan hak-hak asal-usul dalam daerah-daerah yang bersifat istimewa"

Meskipun tidak menyebut secara langsung tentang desa, namun pasal ini menyebut tentang hal asal-usul dalam daerah-daerah yang bersifat istimewa. Pada amandemen UUD 1945 yang kedua pada tahun 2000, Pasal 18 ditambah menjadi beberapa pasal lagi. Salah satunya adalah Pasal 18B yang berisi tentang pengakuan dan penghormatan negara tentang kesatuankesatuan masyarakat hukum adat beserta hak-hak tradisionalnya.

"Negara mengakui dan menghormati kesatuan-kesatuan masyarakat hukum adat beserta hak-hak tradisionalnya sepanjang masih hidup dan sesuai dengan perkembangan masyarakat dan prinsip Negara Kesatuan Republik Indonesia, yang diatur dalam undangundang."

\section{Rezim Pembentukan Desa Menurut Undang-undang Nomor 19 tahun 1965 tentang Pembentukan Desapraja}

Pada tahun 1965, Presiden Soekarno menerbitkan Undang-Undang Nomor 19 Tahun 1965 tentang Pembentukan Desapraja. Pembentukan ini bertujuan untuk mempercepat pembentukan daerah pemerintahan tingkat III. Aturan ini juga menegaskan untuk menghapus unsur-unsur dan sifat-sifat kolonial-feodal yang ada dalam desa.

Menurut Undang-Undang Nomor 19 Tahun 1965 ini, desapraja merupakan badan hukum yang dipimpin oleh seorang Kepala Desapraja. Lebih lanjut dalam pasal 7 disebutkan, "alat-alat kelengkapan Desapraja terdiri dari Kepala Desapraja, Badan Musyawarah Desapraja, Pamong Desapraja, Panitera Desapraja, Petugas Desapraja dan Badan Pertimbangan Desapraja."

Pasal 8 ayat (1) Undang-Undang Nomor 19 Tahun 1965, Kepala Desapraja adalah penyelenggara utama urusan rumah-tangga Desapraja dan sebagai alat Pemerintah Pusat. ayat (2) Kepala Desapraja mengambil tindakan-tindakan dan keputusan-keputusan penting setelah

kemerdekaan, diakses pada tanggal 19 Juni 2021, dalam "Pemerintahan Desa di Setiap Masa Kepresidenan", PurwakartaOnline, https://www.purwakartaonline.com/2021/01/desa-setiap-masapresiden.html, diakses pada tanggal 19 Juni 2021. 
memperoleh persetujuan Badan Musyawarah Desapraja. Pasal 9 ayat (1) Kepala Desapraja dipilih langsung oleh penduduk Desapraja yang sudah berumur 18 tahun atau sudah (pernah) kawin dan menurut adat-kebiasaan setempat sudah menjadi warga Desapraja yang bersangkutan. Ayat (2) Kepala Desapraja diangkat oleh Kepala Daerah tingkat I dari sedikitdikitnya dua dan sebanyak-banyaknya tiga orang calon, berdasarkan hasil pemilihan yang sah, untuk suatu masa jabatan paling lama delapan tahun. Kepala Daerah tingkat I dapat menguasakan kewenangan tersebut kepada Kepala Daerah tingkat II yang bersangkutan. (3) Peraturan pemilihan, pengangkatan dan pengesahan, pemecatan sementara dan pemberhentian Kepala Desapraja ditetapkan oleh Pemerintah Daerah tingkat I dengan memperhatikan adat-kebiasaan setempat. (4) Peraturan termaksud dalam ayat (3) tidak dapat berlaku sebelum disahkan oleh Menteri Dalam Negeri.

Dari hasil penelitian kepustakaan yang dilakukan penulis diperoleh temuan bahwa di dalam Undang-Undang Nomor 19 Tahun 1965 tentang Pembentukan Desapraja. Pengertian desa tidak ditemukan namun yang ada adalah definisi desapraja. Menurut Pasal 1 UndangUndang Nomor 19 Tahun 1965 yang dimaksud dengan Desapraja adalah kesatuan masyarakat hukum yang tertentu batas-batas daerahnya, berhak mengurus rumah tangganya sendiri, memilih penguasanya dan mempunyai harta benda sendiri.

Di dalam ketentuan Undang-Undang Nomor 19 Tahun 1965 tidak ditemukan tentang syarat pembentukan Desa dalam hal ini terkait dengan syarat materiil jumlah kepala keluarga atau jumlah penduduk yang menjadi prasyarat pembentukan desa seperti di dalam Pasal 8 ayat (3) huruf b Undang-Undang Nomor 6 Tahun 2014 tentang Desa. Di dalam Undang-Undang Nomor 19 Tahun 1965 hanya menyebutkan syarat formil pembentukan desa dari desa praja melalui pemerintah tingkat II yang sekarang dikenal dengan tingkat kabupaten. Hal tersebut menyebutkan instrumen hukum atas pembentukan desa dimasa rezim undang-undang tersebut belum mencerminkan keutuhan norma dalam pembentukan desa.

\section{Rezim Pembentukan Desa Menurut Undang-Undang Nomor 5 tahun 1979 tentang Pemerintahan Desa}

Pada masa Orde Baru terjadi perubahan aturan tentang pemerintahan desa melalui Undang-undang No. 5 tahun 1979 tentang Pemerintahan Desa yang disahkan oleh Presiden Soeharto. Undang-Undang ini memperbarui Undang-undang Nomor 19 Tahun 1965. Hal yang signifikan istilah desapraja tidak lagi digunakan dalam aturan ini. Istilah yang digunakan adalah desa. Selain itu, sistem pemerintahan desa dihimbau agar seragam. 
Dalam Pasal 3 disebutkan bahwa pemerintah desa terdiri dari kepala desa dan Lembaga Musyawarah Desa sementara perangkat desa adalah sekretariat desa dan kepala-kepala dusun. Segala hal yang berkaitan dengan pemerintahan dan administrasi desa berada di bawah koordinasi Kementerian Dalam Negeri.

Pasal 2 ayat (1) Undang-Undang Nomor 5 Tahun 1979 Desa dibentuk dengan memperhatikan syarat-syarat luas wilayah, jumlah penduduk dan syarat-syarat lain yang akan ditentukan lebih lanjut dengan peraturan Menteri Dalam Negeri. (2) Pembentukan nama, batas, kewenangan, hak dan kewajiban Desa ditetapkan dan diatur dengan Peraturan Daerah sesuai dengan pedoman yang ditetapkan oleh Menteri Dalam Negeri. (3) Ketentuan tentang pemecahan, penyatuan dan penghapusan Desa diatur dengan Peraturan Menteri Dalam Negeri. (4) Peraturan Daerah yang dimaksud dalam ayat (2), baru berlaku sesudah ada pengesahan dari pejabat yang berwenang.

\section{Rezim Pembentukan desa menurut Undang-Undang No.22 Tahun 1999 tentang Pemerintahan Daerah}

Pada tahun 1999, Presiden Habibie mengeluarkan Undang-Undang No.22 Tahun 1999 tentang Pemerintahan Daerah. Aturan ini muncul salah satunya untuk merevisi penyeragaman nama, bentuk, susunan dan kedudukan pemerintahan desa yang diatur dalam Undang-Undang Nomor 19 Tahun 1965. Aturan sebelumnya dinilai tidak sesuai dengan jiwa Undang-Undang Dasar 1945 dan perlunya mengakui serta menghormati hak asal-usul daerah.

Dalam Undang-Undang Nomor 22 Tahun 1999 Bab XI pasal 94 disebutkan pemerintahan desa meliputi pemerintah desa dan Badan Perwakilan Desa. Pemerintah desa yang dimaksud adalah kepala desa dan perangkat desa sebagaimana dijelaskan dalam pasal 95. Tanggung jawab kepala desa sebagaimana dijelaskan dalam pasal 102, ditujukan kepada rakyat melalui badan perwakilan. Selain itu, kepala desa wajib menyampaikan laporan pelaksanaan tugas kepada Bupati.

Pasal 94 di Desa dibentuk Pemerintah Desa dan Badan Perwakilan Desa, yang merupakan Pemerintahan Desa. Pasal 102 dalam melaksanakan tugas dan kewajiban, sebagaimana dimaksud dalam Pasal 101, Kepala Desa: bertanggung jawab kepada rakyat melalui Badan Perwakilan Desa; dan menyampaikan laporan mengenai pelaksanaan tugasnya kepada Bupati. 


\section{Rezim Pembentukan desa menurut Undang-Undang No. 32 Tahun 2004 tentang}

\section{Pemerintahan Daerah}

Undang-Undang Nomor 22 Tahun 1999 dianggap tidak sesuai dengan perkembangan keadaan, ketatanegaraan, dan tuntutan penyelenggaraan otonomi daerah. Untuk merevisinya, Presiden Megawati mengesahkan Undang-Undang No. 32 Tahun 2004 tentang Pemerintahan Daerah.

Dalam aturan ini, istilah Badan Perwakilan Desa diganti menjadi Badan Permusyawaratan Desa. Selanjutnya, posisi sekretaris desa diisi oleh Pegawai Negeri Sipil yang dianggap mampu. Dalam Pasal 200 ayat (3) ditetapkan desa di Kabupaten/Kota secara bertahap dapat diubah atau disesuaikan statusnya menjadi kelurahan sesuai usul dan prakarsa pemerintah desa bersama badan permusyawaratan desa yang ditetapkan dengan Peraturan Daerah.

Dalam Undang-Undang Nomor 22 Tahun 1999 masa jabatan kepala desa selama sepuluh tahun atau dua kali masa jabatan. Sementara dalam aturan ini, kepala desa menjabat selama enam tahun dan dapat dipilih lagi untuk satu kali masa jabatan.

\section{Perkembangan Pembentukan Desa Menurut Undang-Undang Desa Nomor 6 Tahun 2014}

Pada tahun 2014 Presiden Susilo Bambang Yudhoyono mengesahkan Undang-undang Nomor 6 Tahun 2014 tentang Desa. Mengenai pemerintahan desa, aturan ini menyebut kepala desa sebagai pemerintah desa dibantu oleh perangkat desa. Sementara itu, Badan Permusyawaratan Desa adalah lembaga yang melaksanakan fungsi pemerintahan yang anggotanya merupakan wakil dari penduduk desa.

Tugas, kewenangan, hak, dan kewajiban kepala desa diatur secara rinci dalam Pasal 26. Dalam Pasal 27 dijelaskan kepala desa wajib memberikan laporan pelaksanaan pemerintahan desa kepada Bupati/Walikota, Badan Permusyawaratan Desa, dan masyarakat desa. Mengenai masa jabatan, kepala desa berhak menjabat selama enam tahun. Selanjutnya, yang bersangkutan bisa dipilih lagi sebanyak tiga kali baik secara berturut-turut maupun tidak.

\section{Implikasi Norma Hukum Maladministrasi dalam Pembentukan Desa Definitif Norma Perintah Sebagai Hak dalam Pembentukan Desa Yang Maladministrasi}

Norma sebagai perintah jika dikaitkan dengan pembentukan dan dasar rasio legis lahirnya Undang-Undang Nomor 6 Tahun 2014 tentang Desa mengandung norma perintah hal ini terurai di dalam ketentuan Pasal 8 ayat (3) huruf b angka 6 berbunyi: Wilayah Sulawesi Tengah, Sulawesi Barat, Sulawesi Tenggara, Gorontalo, dan Kalimantan Selatan paling sedikit 2.000 jiwa 
atau 400 kepala keluarga. Rasio legis dari ketentuan Pasal 8 ayat (3) huruf b di dalam UndangUndang Desa adalah jika jumlah penduduk dengan tingkat kepadatan yang banyak maka prasyarat jumlah penduduk dalam pembentukan desa akan semakin besar begitu pula sebaliknya daerah yang memiliki jumlah penduduk yang lebih rendah maka prasyarat jumlah penduduk dalam pembentukan desa juga akan semakin sedikit atau dengan kata lain pembentukan desa didasarkan pada klaster jumlah kepadatan penduduk suatu daerah. Perbedaan syarat pembentukan desa dalam ketentuan Pasal 8 ayat (3) huruf b di dalam Undang-Undang Desa menunjukkan bahwa proses persebaran penduduk dan pembangunan di Indonesia tidak mereta hal ini sebagai konsekuensi logis dari sistem sentralistis yang terjadi sebelum era reformasi.

Ketentuan Pasal 8 ayat (3) Undang-Undang Nomor 6 Tahun 2014 tentang Desa sangat jelas mengandung norma perintah artinya setiap daerah Kabupaten yang telah memenuhi syarat dapat membentuk desa baru yang terlebih dahulu menjadi desa persiapan sebelum menjadi desa definitif. Secara konstitusional pasal 8 ayat 3 Undang-Undang Nomor 6 Tahun 2014 tentang Desa mengandung norma perintah sebagai hak.

Dalam literatur berbahasa Inggris kerap kali dikemukakan bahwa hak berdasarkan hukum (legal right) dibedakan dari hak yang timbul dari norma lain7. Menurut Paton, hak berdasarkan hukum biasanya diartikan sebagai hak yang diakui dan dilindungi oleh hukum ${ }^{8}$. Istilah hak pertama kali dikenal dalam hukum sebagai Ius yang dikenal dalam hukum romawi dan pengaruhnya masih dirasakan di beberapa Negara seperti skotlandia dan Negara Eropa kontinental. Hak mulai menjadi tema sentral perbincangan seiring dengan munculnya negaranegara nasional yang mempersoalkan hubungan antara dengan warga negara dan yang mengenai masalah hak-hak yang dimiliki oleh individu terhadap negara terutama terhadap pemerintah yang memerintah warga negara.

Dalam pendekatan teori yang bersifat konseptual hak dikenal yakni9 ${ }^{9}$ Hak-hak yang sempurna dan tidak sempurna. Hak-hak yang sempurna adalah yang dapat dilaksanakan melalui hukum seperti kalau perlu melalui pemaksaan oleh hukum. Hak yang tidak sempurna

\footnotetext{
G. W. A. Paton, Textbook of Jurisprudence. English Language Book Society. London: Oxford University Press. 1972.

8 Ibid. Lihat juga di Peter Mahmud Marzuki, Pengantar Ilmu Hukum, Jakarta: Kencana, 2016, hlm. 142.

9 Muhammad Syukri Albani Nasution, dkk, Hukum Dalam Pendekatan Filsafat. Kencana: Jakarta, 2017, hlm. 57-58.
} 
adalah yang diakui oleh hukum tetapi tidak selalu dilaksanakan oleh pengadilan, seperti hak yang dibatasi oleh lembaga daluwarsa ${ }^{10}$.

Menurut penulis ketentuan pasal 8 ayat (3) huruf b ke 6 Undang-Undang Nomor 6 Tahun 2014 tentang Desa mengandung makna hak yang bersifat sempurna dimana pembentukan dilegitimasi secara konstitusional oleh undang-undang dengan syarat dan ketentuan yang telah ditetapkan oleh undang-undang tersebut sebagai hukum. Meskipun pembentukan desa merupakan hak yang sempurna namun dapat dimungkinkan dalam praktik empiris terjadi penyimpangan hak dan atau penyalahgunaan hak oleh kekuasaan sebagai pemilik otoritas hukum dalam pembentukan desa dalam hal ini pemerintah Kabupaten Konawe dan Dewan Perwakilan Rakyat Daerah Kabupaten Konawe yang secara konstitusional sebagai alat negara.

Penyalahgunaan hak dalam pembentukan desa telah dipraktikkan secara empiris dimana terdapat 56 desa yang dibentuk dengan menyalahgunakan prinsip hak (misbruik van recht). Suatu adagium kuno berbunyi: neminem loedit qui suo iure utitur, yang terjemahan bebasnya adalah "tidak seorang pun dirugikan oleh penggunaan hak". Berdasarkan adagium itulah dikembangkan pemikiran bahwa penggunaan suatu tindakan menurut hukum, sehingga tidak dapat secara sekaligus juga menghasilkan suatu tindakan yang melanggar hukum ${ }^{11}$.Oleh karena itu. Kerap kali dikatakan bahwa istilah penyalahgunaan hak merupakan suatu contradictio in terminis atau setidaknya suatu istilah yang mengandung kerancuan berpikir (dubious) ${ }^{12}$.Akan tetapi, sejak dahulu telah diterima bahwa tidak semua penggunaan hak diperkenankan. Suatu ungkapan dinyatakan oleh gaius, seorang ahli hukum romawi kuno yang berbunyi male enim no strop iure uti non debimus yang artinya kita tidak boleh menggunakan hak kita untuk tujuan yang tidak baik."

Menurut penulis pembentukan desa di Kabupaten Konawe yang meliputi 56 desa telah melanggar ungkapan male enim no strop iure uti non debimus. Pernyataan ini penulis sampaikan bahwa pembentukan desa merupakan hak yang diberikan oleh hukum sebagai hak yang sempurna atau hak yang absolut dimana pemerintah Kabupaten Konawe berhak membentuk Desa berdasarkan prinsip kewenangan yang diberikan oleh hukum namun demikian terjadi penyalahgunaan hak yang dilakukan oleh pemerintah Kabupaten Konawe dalam pembentukan desa tersebut yang telah berimplikasi pada kerugian negara. Penggunaan hak untuk tujuan yang

\footnotetext{
10 Lili Rasyidi dan Ira Thania Rasyidi, Pengantar Filsafat Hukum, Bandung: Mandar Maju, 2010, hlm. 122125. Lihat juga K. Bertens, Etika, Yogyakarta: Kanisius, 2013, hlm. 145-150. Dalam Amran Suadi, Refleksi Filsafat Pancasila, Hak Asasi Manusia, dan Etika Jakarta: Kencana, 2019, hlm. 139.

11 P. van Dijk, dikutip Peter Mahmud Marzuki, Pengantar Ilmu Hukum, Jakarta: Kencana, 2013. hlm. 155

12 Ibid.
} 
salah bertentangan dengan prinsip etis atas konsepsi hak itu sendiri olehnya itu pembentukan desa yang terjadi di Kabupaten Konawe bertentangan dengan norma perintah sebagai hak sehingga kedudukan hukum atas pembentukan desa tersebut tidak memenuhi unsur kelayakan norma.

\section{Norma Kewajiban dalam Pembentukan Desa Yang Maladministrasi}

Hubungan hukum adalah hubungan antara dua orang atau lebih, kedua belah pihak mempunyai hak dan kewajibannya masing-masing, jadi hubungan hukum mempunyai dua segi yaitu: bevoegdhied (kekuasaan, kewenangan, atau hak) dengan lawannya plich atau kewajiban. Kewajiban merupakan suatu bentuk pemenuhan atas hak karena hubungan hukum. Dalam konteks ini lahir dan timbulnya suatu Kewajiban, disebabkan oleh hal sebagai berikut, yaitu²:

1. Karena diperoleh suatu hak yang membebani syarat untuk memenuhi kewajiban.

2. Berdasarkan suatu perjanjian yang telah disepakati.

3. Adanya kesalahan atau kelalaian seseorang yang menimbulkan kerugian bagi orang lain, sehingga ia wajib membayar ganti rugi.

4. Karena telah menikmati hak tertentu yang harus diimbangi dengan kewajiban tertentu.

5. Karena daluwarsa (verjaring), contoh denda

Berdasarkan teori tentang timbulnya kewajiban maka dalam hal pembentukan desa definitif yang maladministrasi karena penyalahgunaan hak maka akan berkonsekuensi pada timbulnya kewajiban untuk membatalkan pembentukan desa oleh pemerintah Kabupaten Konawe sebagaimana yang dimaksud timbulnya kewajiban karena kesalahan yang melanggar hukum yang menimbulkan kerugian. Kesalahan yang melanggar hukum karena pemerintah daerah telah melakukan perbuatan melanggar hukum pasal 8 ayat (3) huruf b angka 6 yang menimbulkan kerugian terhadap keuangan negara sebesar Rp. 120.924.344.000 (Seratus Dua Puluh Milyar Sembilan Ratus Dua Puluh Empat Juta Tiga Ratus Empat Puluh Empat Ribu Rupiah) oleh sebab itu akibat kerugian negara tersebut menimbulkan kewajiban yang dapat menghapus hak dalam hal ini kewajiban untuk mengembalikan pembentukan desa sesuai dengan syarat ketentuan pasal 8 ayat (3) huruf b angka 6 Undang-Undang Nomor 6 Tahun 2014 tentang Desa. Kewajiban menurut penulis mengharuskan mengembalikan keadaan hukum

\footnotetext{
13 Lukman Santoso AZ \& Yahyanto, Pengantar Ilmu Hukum, Malang: Setara Press, 2016, hlm. 88-89.
} 
yang semula sesuai dengan apa yang telah ditentukan oleh pembentuk undang-undang tentang Desa.

Secara konseptual dalam doktrin teori hukum kewajiban dikenal dengan istilah Kewajiban yang positif dan negatif. Kewajiban positif yang menghendaki dilakukannya perbuatan positif seperti kewajiban untuk mengembalikan desa dalam keadaan semula dalam hal ini desa-desa yang tidak memenuhi syarat menurut Pasal 8 ayat (3) hurufb angka 6 UndangUndang Nomor 6 Tahun 2014 tentang Desa dikembalikan pada desa induk dan atau mengembalikan sesuai dengan teknis prosedur yang berlaku sehingga tidak menimbulkan kecacatan hukum dalam pembentukan desa tersebut. Adapun kewajiban negatif adalah yang menghendaki suatu pihak tidak melakukan sesuatu seperti kewajiban seseorang untuk tidak melakukan sesuatu yang mengganggu milik tetangganya.

Menurut penulis, Undang-Undang Nomor 6 Tahun 2014 tentang Desa tidak menjelaskan tentang pembatalan desa yang dibentuk tidak memenuhi syarat menurut ketentuan Pasal 8 ayat (3) huruf b angka 6 UU Nomor 6 Tahun 2014 tentang Desa dimana pembentukan desa untuk wilayah Provinsi Sulawesi Tenggara jumlah Penduduk 2000 jiwa atau setara dengan 400 kepala keluarga serta pembentukan desa minimal 5 tahun desa persiapan untuk menjadi desa definitif. Ketentuan tersebut tentang pembatalan desa sebagaimana yang dimaksud di atas tidak ditemukan di dalam Undang-Undang Nomor 6 Tahun 2014 tentang Desa, kebiasaan, yurisprudensi, perjanjian sebagai sumber hukum formal namun pembatalan desa tersebut dapat ditemukan dalam doktrin teori kewajiban positif dimana yang menyatakan segala sesuatu yang tidak memenuhi syarat harus dikembalikan kepada seseorang yang memberikan objek tertentu artinya desa yang tidak memenuhi syarat harus dikembalikan pada desa induk sebagaimana perintah norma kewajiban yang bersifat positif.

\section{KESIMPULAN}

Rezim perkembangan pembentukan desa sebelum dan sesudah berlakunya Undang-Undang Nomor 6 Tahun 2014 mengalami beberapa perubahan terkait kebijakan hukum pembentukan Desa sebelum berlakunya Undang-Undang Nomor 6 Tahun 2014 tentang Desa pembentukan desa menjadi kewenangan pemerintah tingkat II yang kemudian kewenangan pembentukan Desa harus melalui keputusan Menteri Dalam Negeri yang selanjutnya pembentukan Desa diatur kembali dan kewenangan pembentukan Desa dikembalikan kepada Pemerintah Daerah namun belum mengatur tentang syarat jumlah Penduduk dan jumlah Kepala Keluarga sebagai syarat pembentukan. Setelah berlakunya Undang-Undang Desa pembentukan Desa telah diatur 
pada level peraturan undang-undang dimana syarat dan ketentuan pembentukan desa tertuang di dalam pasal 8 ayat 3 huruf b ke 6. Undang-Undang Desa Nomor 6 Tahun 2014. Dalam hal implikasi atas norma pembentukan desa yang maladministrasi maka pembentukan desa sebagai norma perintah merupakan suatu hak dimana pemerintah daerah dapat membentuk desa yang harus didahului desa persiapan selama 5 tahun dengan syarat dan ketentuan dan pembentukannya mengacu pada pasal 8 ayat 3 Undang-Undang Nomor 6 Tahun 2014 tentang Desa. Terhadap norma larangan atas pembentukan desa di Kabupaten Konawe dari hasil penelitian ditemukan bahwa pembentukan desa telah melanggar norma larangan karena tidak memenuhi syarat pembentukan desa sebagaimana yang dimaksud dalam Undang-Undang Desa.

\section{Daftar Pustaka}

\section{Buku}

AZ, Lukman Santoso \& Yahyanto, Pengantar Ilmu Hukum, Malang: Setara Press, 2016.

Bertens, K., Etika, Yogyakarta: Kanisius, 2013.

Marzuki, Peter Mahmud, Pengantar Ilmu Hukum, Jakarta: Kencana, 2016.

Nasution, Muhammad Syukri Albani, dkk, Hukum Dalam Pendekatan Filsafat. Kencana: Jakarta, 2017.

Paton, G. W. A., Textbook of Jurisprudence. English Language Book Society. London: Oxford University Press. 1972.

Rasyidi, Lili dan Ira Thania Rasyidi, Pengantar Filsafat Hukum, Bandung: Mandar Maju, 2010.

Suadi, Amran, Refleksi Filsafat Pancasila, Hak Asasi Manusia, dan Etika Jakarta: Kencana, 2019.

\section{Jurnal dan Makalah}

Muin, Fatkhul dan Rully Syahrul Mucharom, “Desa dan Hukum Adat: Perspektif Normativitas dan Sosiologis Keindonesiaan", Prosiding Seminar Nasional Multi Disiplin Ilmu \& Call For Papers Unisbank (SENDI_U) Ke-2 Kajian Multi Disiplin Ilmu dalam Pengembangan IPTEKS untuk Mewujudkan Pembangunan Nasional Semesta Berencan (PNSB) sebagai Upaya Meningkatkan Daya Saing Global, Semarang: Universitas Stikubank, 2016.

Puspitasari, Hanna Eka dan Andy Fefta Wijaya,Sukanto, “Pemekaran Desa dalam Rangka Peningkatan Pelayanan Publik di Bidang Kesehatan Berkebutuhan Khusus (Studi Pada Desa Sidoharjo, Kec. Sukorejo, Kab. Ponorogo, Jawa Timur)" Jurnal Administrasi Publik (JAP), Vol. 1, No. 2, 2020. 
Sumarlis, "Kajian Tujuan Pemekaran Desa Menurut Peraturan Pemerintah Nomor 129 Tahun 2000 (Studi Kasus: Desa Kampung Baru Koto Kecamatan Inuman)”, Jurnal Perencanaan, Sains, Teknologi, dan Komputer, Vol. 1, No. 1, 2018.

\section{Peraturan Perundang-undangan}

Undang-Undang Nomor 1 Tahun 2004 tentang Perbendaharaan Negara

Undang-Undang Nomor 20 tahun 2001 tentang Perubahan atas Undang-Undang Nomor 31

Tahun 1999 tentang Pemberantasan Tindak Pidana Korupsi

Undang-Undang Nomor 15 Tahun 2006 tentang Badan Pemeriksa Keuangan

Undang-Undang Nomor 6 Tahun 2014 tentang Desa.

Undang-Undang Nomor 23 Tahun 2014 tentang Pemerintah Daerah

Undang-Undang Nomor 30 Tahun 2014 tentang Administrasi Pemerintahan

Undang-Undang Nomor 37 Tahun 2008 tenang Ombudsman Republik Indonesia

Perda Kabupaten Konawe Nomor 7 Tahun 2011 tentang Perubahan atas Peraturan Daerah

Nomor 2 Tahun 2011 tentang Pembentukan dan Pendefinisian Desa-desa dalam Wilayah Kabupaten Konawe

Perda Kabupaten Konawe Nomor 1 Tahun 2014 tentang Pembentukan dan Pendefinisian Desadesa

\section{Situs Web}

"Pemerintahan Desa di Setiap Masa Kepresidenan", PurwakartaOnline, https://www.purwakartaonline.com/2021/01/desa-setiap-masa-presiden.html, diakses pada tanggal 19 Juni 2021.

Gitiyarko, Vincentius, "Sejarah Pemerintah Desa Setelah Kemerdekaan", Kompaspedia, https://kompaspedia.kompas.id/baca/paparan-topik/sejarah-pemerintahan-desasetelah-kemerdekaan, diakses pada tanggal 19 Juni 2021.

Kartika, Mimi, Friska Yolanda, "Kemendagri Usul Pemda Lakukan Evaluasi Desa”, Republika, https://republika.co.id/berita/q15xjj370/kemendagri-usul-pemda-lakukan-evaluasidesa, diakses pada tanggal 14 Juni 2021. 